\title{
Tree crown size as a measure of tree biosocial position in 135-year-old oak (Quercus L.) stand
}

\author{
Katarzyna Kaźmierczak ${ }^{1}$, Bogna Zawieja² \\ ${ }^{1}$ Poznań University of Life Sciences, Department of Forest Management, Wojska Polskiego 71c, 60-625 Poznań, Poland \\ ${ }^{2}$ Poznań University of Life Sciences, Department of Mathematical and Statistical Methods, Wojska Polskiego 28, \\ 60-637 Poznań, Poland, phone: +48 61 8487153, e-mail: bogna13@up.poznan.pl
}

\section{Abstract}

The paper presents an attempt to apply measurable traits of a tree - crown projection area, crown length, diameter at breast height and tree height for classification of 135-year-old oak (Quercus L.) trees into Kraft classes. Statistical multivariate analysis was applied to reach the aim. Empirical material was collected on sample plot area of $0.75 \mathrm{ha}$, located in 135-year-old oak stand. Analysis of dimensional traits of oaks from 135-year-old stand allows quite certain classification of trees into three groups: pre-dominant, dominant and co-dominant and dominated ones. This seems to be quite promising, providing a tool for the approximation of the biosocial position of tree with no need for assessment in forest. Applied analyses do not allow distinguishing trees belonging to II and III Kraft classes. Unless the eye-estimation-based classification is completed, principal component analysis (PCA) method provided simple, provisional solution for grouping trees from 135-year-old stand into three overmentioned groups. Discriminant analysis gives more precise results compared with PCA. In the analysed stand, the most important traits for the evaluation of biosocial position were diameter at breast height, crown projection area and height.

\section{KeY WORDS}

crown length, crown projection area, discriminant analysis, Kraft classes, LDA, PCA

\section{INTRODUCTION}

Evaluation of stand growth dynamics demands research interests to be focused at single tree as well: its dimensions, age, increments, size of crown and its elements so as growth space - considering properties of various species. Even-aged and pure stands are not set of identical trees. They consist of variated individuals interacting amongst themselves in many aspects. Differentiation of trees as a result of competition for light, growth space and nu- trients availability is also determined by growth energy and adaptive ability of individual trees (Jaworski 2004). Many systems of tree classification have been developed, mainly for economically managed stands, although some of them may be applied in other circumstances as well. The eldest systems were applied in mid-nineteen century, as Seebach in 1843 distinguished four classes of trees: dominant, dominated, secreted and drowned out, whilst Burckhardt in 1848 classified trees into six different classes: pre-dominant, dominant, moderately dominant 
and weak dominant in main stand versus dominated and overshadowed trees beneath the former (Jaworski 2004).

Classification system most frequently in use is the one proposed by Kraft (1884), called 'natural' or 'biological' by the author himself (Fig. 1).

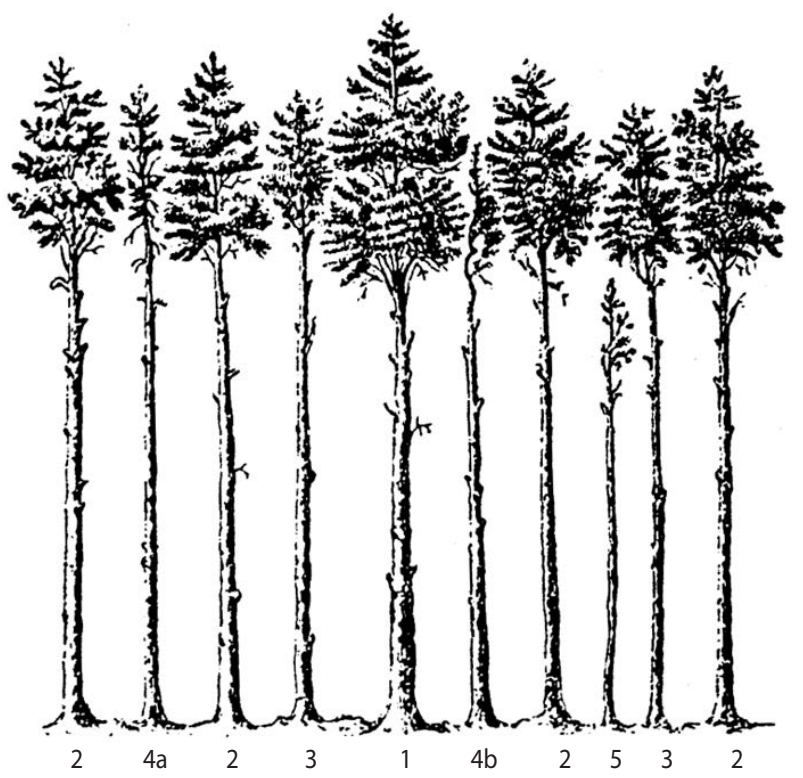

Figure 1. Tree classes according to Kraft (1884, after Assmann 1970)

It describes social position of trees as combination of height in comparison to neighbouring trees so as crown size and quality. According to the classification, trees can be counted into one of the groups of equal 'growth energy':

1. Pre-dominant trees, apparently higher to the surroundings, with crowns protruding over stand canopy, with very well-developed crowns.

2. Dominant, forming the main canopy of stand, with well-developed crowns.

3. Co-dominant, slightly lower than the formers, with crowns confined at sides.

4. Dominated trees, apparently lower, with ill-formed, irregular in shape, confined crowns:

- crowns highly confined but with free top in the layer of co-dominant trees,

- crowns even more confined and partly overshadowed, with top beneath the canopy of co-dominant trees.

5. Overshadowed trees:
- with alive crowns,

- with withered crowns.

Tree of class 1-3 compose the so-called dominant stand, whilst those of class 4 and 5 the dominated stand.

Kraft's classification system is often criticised as subjective and not considering stem quality. However, as shown by research in silviculture, the share of trees in dominating and dominated stands corresponds well with their participation in total volume production (Jaworski 2004). Results of research by Kaźmierczak (2010, 2012b, 2013a, b) on growth space of single trees in pine stands led to the conclusion that position of a tree described by Kraft's classification is highly correlated with measured traits of trees, concerning equally dimensional traits (diameter at breast height (DBH), height, thickwood volume and crown projection area) and incremental ones (five-year increments of height, $\mathrm{DBH}$, basal area and volume). The lower the class, the smaller were the over mentioned traits of trees.

Crown of tree plays a key role in its growth, determining the assimilation process and its effectiveness in the growth of a tree. Size of a crown is also decisive in occupying the growth space of a tree. However, very few wide descriptions of oak crowns and their influence on volume increment can be found in Polish bibliography. Majority of investigation is focused on Scots pine crowns (Lemke 1966, 1968), which is obvious considering that the latter is the most common and economically the most important species in Polish forests, occupying $70.5 \%$ of area. Share of oak stands in total area of Polish forests reaches 7.9\% (Leśnictwo 2014), and in recommended species, composition for forest regeneration takes second place after Scots pine, reaching 17\%.

Classification of trees to the Kraft classes may be subjective. However, total share of trees in dominating and dominated stands determines the share in stand productivity. According to Korpel (after Jaworski 2004), dominating stand comprises about $70 \%$ of trees. Their basal area composes $80 \%$ of total basal area of stand, whilst their thickwood volume is almost $90 \%$. Trees of highest position also have the biggest increments. Dominated trees play rather a tending role to dominant ones.

The current work is an attempt of applying measurable traits of a tree (crown projection area, crown length, DBH and tree height) for the classification of 135-yearold oak trees to the Kraft classes. Statistical multivariate analysis was applied to reach the aim. 


\section{MATERIAL AND METHODS}

Empirical material was collected on sample plot area of 0.75 ha, located in 135 -year-old oak stand on moderately humid deciduous forest site. The stand on the plot comprised 160 trees in total, including 152 oaks and 8 pines. Only the oaks were considered for further analysis. As only one tree was classified into Kraft class V, it was included into joined class with the IV.
Following traits of each tree were measured:

$-d_{1.3}-$ the DBH outside bark in two perpendicular directions $(\mathrm{N}-\mathrm{S}$ and $\mathrm{W}-\mathrm{E})$ to the nearest $0.1 \mathrm{~cm}$. Arithmetic mean of the two measures was treated as real diameter of tree.

- $h$ - the tree height (accuracy to $0.1 \mathrm{~m}$ )

- $p_{k}$-the crown projection area as polygonal area with projections of characteristics point of a crown: their locations were established with mirror-based crown

Table 1. Characteristics of oaks in the stand and within Kraft classes

\begin{tabular}{|c|c|c|c|c|c|c|c|}
\hline \multirow{2}{*}{ Trait } & \multirow{2}{*}{$\begin{array}{l}\text { Descriptive } \\
\text { statistic }\end{array}$} & \multirow{2}{*}{$\begin{array}{c}\text { Entire } \\
\text { stand }\end{array}$} & \multicolumn{3}{|c|}{ Kraft class } & \multirow{2}{*}{$\begin{array}{l}\text { Dominating } \\
\text { stand }\end{array}$} & \multirow{2}{*}{$\begin{array}{l}\text { Dominatec } \\
\text { stand }\end{array}$} \\
\hline & & & I & II & III & & \\
\hline \multirow{6}{*}{$\begin{array}{l}\text { Diameter } \\
d_{1.3}[\mathrm{~cm}]\end{array}$} & no. of trees & 152 & 11 & 100 & 26 & 137 & 15 \\
\hline & minimum & 12.10 & 47.30 & 31.15 & 25.95 & 25.95 & 12.10 \\
\hline & maximum & 65.90 & 65.90 & 65.00 & 51.05 & 65.90 & 26.45 \\
\hline & mean & 41.41 & 59.04 & 44.15 & 35.10 & 43.63 & 21.20 \\
\hline & standard deviation & 10.93 & 6.28 & 7.12 & 6.52 & 9.00 & 4.08 \\
\hline & $\mathrm{CV} \%$ & 26.40 & 10.64 & 16.13 & 18.59 & 20,63 & 19.24 \\
\hline \multirow{5}{*}{$\begin{array}{l}\text { Height } \\
\mathrm{h}[\mathrm{m}]\end{array}$} & minimum & 11.50 & 29.70 & 25.40 & 22.50 & 22.50 & 11.50 \\
\hline & maximum & 34.60 & 34.60 & 33.30 & 28.40 & 34.60 & 24.70 \\
\hline & mean & 28.55 & 32.27 & 30.01 & 26.37 & 29.50 & 19.91 \\
\hline & standard deviation & 3.70 & 1.31 & 1.33 & 1.35 & 2.11 & 3.98 \\
\hline & $\mathrm{CV} \%$ & 12.97 & 4.05 & 4.45 & 5.13 & 7.15 & 19.98 \\
\hline \multirow{5}{*}{$\begin{array}{l}\text { Crown project-tion area } \\
p_{k}\left[\mathrm{~m}^{2}\right]\end{array}$} & minimum & 0.28 & 61.94 & 6.95 & 6.01 & 6.01 & 0.28 \\
\hline & maximum & 139.06 & 139.06 & 95.50 & 49.56 & 139.06 & 30.54 \\
\hline & mean & 37.24 & 103.72 & 37.28 & 21.91 & 39.69 & 14.84 \\
\hline & standard deviation & 26.74 & 26.74 & 17.66 & 12.10 & 26.51 & 8.71 \\
\hline & $\mathrm{CV} \%$ & 70.81 & 25.78 & 47.38 & 55.23 & 66.79 & 58.71 \\
\hline \multirow{5}{*}{$\begin{array}{l}\text { Crown length } \\
l_{k}[\mathrm{~m}]\end{array}$} & minimum & 2.30 & 12.10 & 6.50 & 4.30 & 4.30 & 2.30 \\
\hline & maximum & 18.40 & 18.40 & 15.90 & 11.10 & 18.40 & 9.30 \\
\hline & mean & 10.53 & 15.16 & 11.20 & 8.48 & 11.00 & 6.23 \\
\hline & standard deviation & 3.00 & 2.41 & 2.24 & 1.75 & 2.70 & 2.04 \\
\hline & $\mathrm{CV} \%$ & 28.47 & 15.89 & 19.99 & 20.61 & 24.53 & 32.70 \\
\hline \multirow{5}{*}{$\begin{array}{l}\text { Relative crown length } \\
l_{k} / h\end{array}$} & minimum & 0.16 & 0.37 & 0.22 & 0.16 & 0.16 & 0.18 \\
\hline & maximum & 0.62 & 0.62 & 0.52 & 0.42 & 0.62 & 0.45 \\
\hline & mean & 0.36 & 0.47 & 0.37 & 0.32 & 0.37 & 0.31 \\
\hline & standard deviation & 0.08 & 0.08 & 0.07 & 0.06 & 0.08 & 0.08 \\
\hline & CV \% & 21.77 & 3.44 & 3.72 & 3.96 & 4.18 & 5.06 \\
\hline
\end{tabular}

$\mathrm{CV}-$ Coefficient of variation. 
projector and the area was calculated using polar method (distance from tree stump in centimetres and azimuth to $1^{\circ}$ )

- $l_{k}$ - the height of live crown basis (with accuracy to $0.1 \mathrm{~m})$

In the case of analyzed data can be stated that means of traits increases conformably with increase of the position in classification. Variability of traits within classes is - in many cases - apparently smaller than that in entire lot of trees (see Tab. 1). To visualise the dimensional characteristics of the trees divided into Kraft classes, each tree is presented as a match (Fig. 2). The length of match presents height of tree $(h)$, length of match head presents length of crown $\left(l_{k}\right)$, the width of match presents the diameter of tree $\left(d_{1.3}\right)$ and the width of match head presents the diameter of field crown projection $\left(p_{k}\right)$.

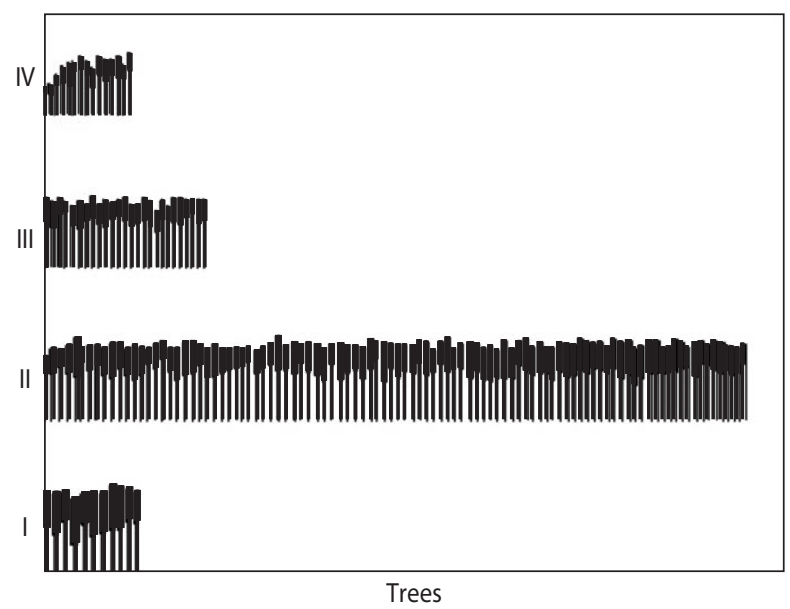

Figure 2. Results of the measurements of dependence of traits (each match presents $d_{1.3}, h$, diameter of $p_{k}$ and $l_{k}$ of one tree)

\section{Principal component analysis (PCA)}

In this method, a linear combination is used to transform the $p$-dimensional-correlated observations

$$
x_{i}=\left(x_{i 1}, x_{i 2}, \ldots, x_{i p}\right)^{\prime}
$$

(otherwise, for uncorrelated data, the application of data reduction using principal component analysis (PCA) causes large loss of information). New, uncorrelated, transformed variables are

$$
z_{j}=a_{j 1} x_{j 1}+a_{j 2} x_{j 2}+\ldots+a_{j p} x_{j p}=a_{j}{ }^{\prime} x_{j}
$$

In this transformation, it is assumed that the vectors of coefficients $a_{j}$ must have the length 1 and the variance of the variables $z_{j}$ is the maximum (Krzyśko 2000a).

\section{Discriminant analysis (LDA method)}

In this method, the $p$-dimensional observations are transformed to new variables

$$
u_{j}=b_{j 1} x_{j 1}+b_{j 2} x_{j 2}+\ldots+b_{j p} x_{j p}
$$

$(j=1,2, \ldots, s$ and $s \leq p)$ using the linear combination such as PCA. These functions are determined by the following conditions: the variables $u_{j}$ are uncorrelated and the level of diversification classes must be the maximum. This level of diversification is dependent on the two covariation matrices: total and inter-classes. Variables $u_{j}$ are named the discriminant variables that to the maximum extent differentiate groups.

Presenting the transformed observations in the plane of the first two discriminatory variables, a graphical representation of the analysed data was obtained (Krzyśko 2000b; Kaźmierczak and Zawieja 2015). If the analysed characteristics of good differentiate the group, then they can be separated linearly. In the linear discriminant analysis (LDA) method, on the basis of classified data, the classification functions are determined for the classification of new data into one of the classes. The square classifier is most often applied here (Krzyśko 2000b).

The assessment of the discriminant function was performed using the cross-validation method. This method involves the removal of same cases from the data set. For the reduced data set, the discriminant functions are determined; then using these functions, the removed cases are classified and next the numbers of mistakes are assessed. In the present study, crossvalidation method was performed by removing the data from each observation separately and then was classified by counting the number of errors. Owing to the large differences between sizes of classes, proportional priors are assumed.

All calculation were performed using the STATISTICA 10 package; moreover, the Scilab 5.4.1 software was used for graphical presentation of data. 


\section{Results}

Before the application of the PCA, the correlation coefficient and their significance can be calculated (Tab. 2). Because all these coefficients were highly significant ( $p<0.0001$ in all cases), it was appropriate to use this analysis.

Table 2. Pearsons correlation coefficients

\begin{tabular}{|c|c|c|c|c|}
\hline & $d_{1.3}$ & $\mathrm{~h}$ & $\mathrm{p}_{\mathrm{k}}$ & $\mathrm{l}_{\mathrm{k}}$ \\
\hline$d_{1.3}$ & 1 & & & \\
\hline$h$ & $0.763^{*}$ & 1 & & \\
\hline$p_{k}$ & $0.791^{*}$ & $0.473^{*}$ & 1 & \\
\hline$l_{k}$ & $0.690^{*}$ & $0.701^{*}$ & $0.630^{*}$ & 1 \\
\hline
\end{tabular}

* the significance on the 0.001 level.

\section{PCA}

The projection of analysed multi-dimensional observations of individual trees onto a plane was obtained after the application of PCA (Fig. 3). The axes were the two first main components, which together explained $98.94 \%$ of the total variability (the first component explains most of the total variability $-93.29 \%$ ). The plotted points of the tree were linearly separated into three groups. In the first group, trees (on the left) were classified into Kraft class IV, the second tree belonged to classes II and III and the third belonged to class I (with few exceptions). Most of the tress from classes II and III could also be linearly separated, but this division is not too clear.

Table 3. The absolute contribution of variables in the first two principal components and general standardized canonical coefficients

\begin{tabular}{|c|c|c|c|c|c|}
\hline Trait & PC1 & PC 2 & PC 3 & Can1 & Can2 \\
\hline$d_{1.3}$ & 0.111 & 0.730 & 0.138 & 0.283 & 0.744 \\
\hline$h$ & 0.005 & 0.133 & 0.406 & 0.822 & 0.136 \\
\hline$p_{k}$ & 0.879 & 0.117 & 0.001 & 0.128 & 1.382 \\
\hline$l_{k}$ & 0.005 & 0.020 & 0.455 & - & - \\
\hline
\end{tabular}

The contribution of variables in the principal components was dealt (see Tab. 3). In the first principal component, most of the contribution had trait $p_{k}$; in the second principal component, most of the contribution had trait $d_{13}$; and in the third principal component, most of the contribution had traits $h$ and $l_{k}$, but this component explained only $0.76 \%$ of the total variability.
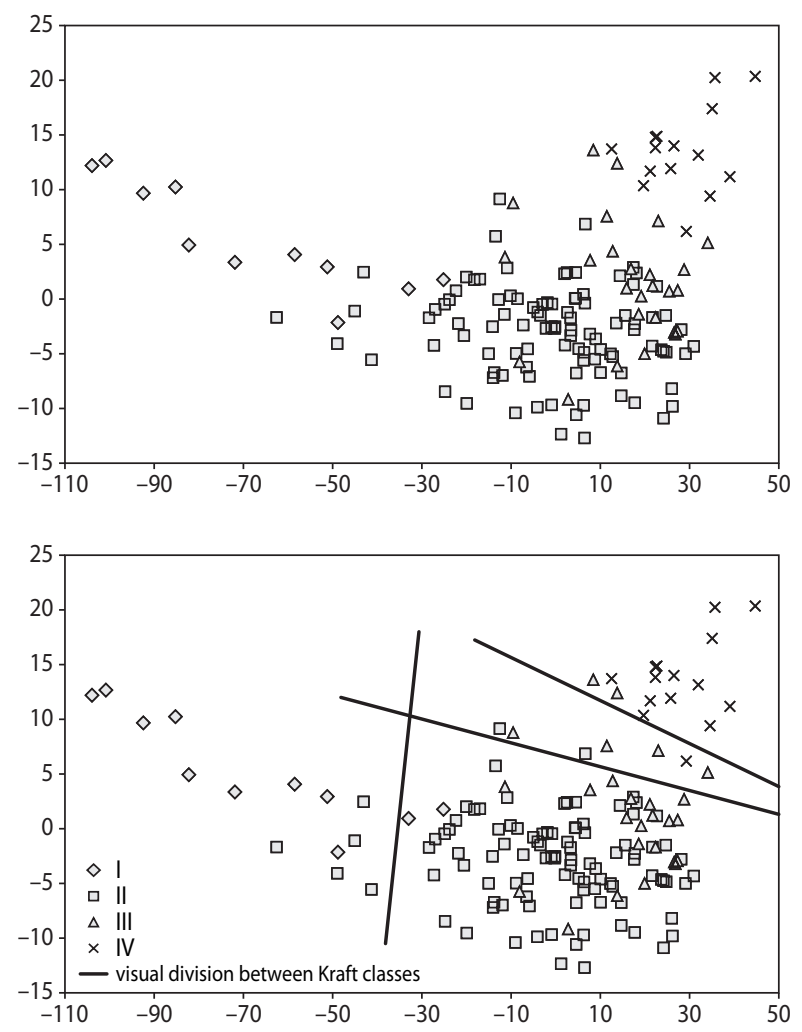

Figure 3. The projection of the observations onto plane of two first principal components

\section{Discriminant analysis}

Variables of discriminant analysis were selected using the stepwise forward method. Consequently, three traits, $d_{1.3}, h$ and $p_{k}$, were selected to the model. On the basis of these traits, discriminant functions and discriminant variables were determined. The first two discriminant variables significantly differentiated the groups (for the first variable, the significance of $\Lambda$-Wilks statistic was $p<0.0001$ and for the second variable, $p<0.0001$, whilst for the third variable, $p<0.8358$ ). Just like after using the PCA, majority of the points of the trees classified as class IV and class I were linearly separated (see Fig. 4). It was also possible to designate a line separating the classes II and III, but the distance between the classes is much smaller than that from class I to II and from IV to III. 

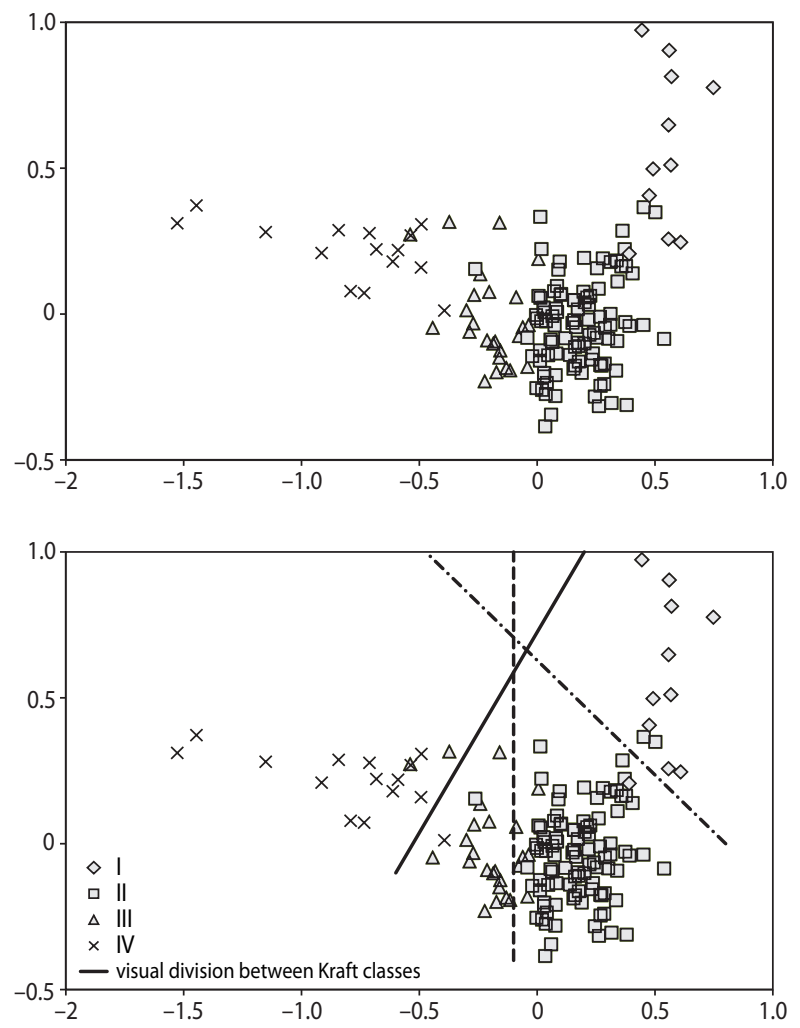

Figure 4. The projection of the observations onto plane of two first discriminant variables
On the basis of the absolute value of the standardised canonical coefficients (Tab. 3). it can be noticed that the largest contribution in the first discriminant variable had traits $h$ and $d_{1.3}$ and that in the second variable had traits $p_{k}$ and $d_{1.3}$ (the sign of the standardised coefficients does not matter for interpretation).

As a result of using the square classification function, it was found that most of the trees had been correctly classified into classes from which they were the source (Tab. 4).

On the basis of the cross-validation method, it was again computed that most of the trees were correctly classified into the Kraft classes (Tab. 4). The greatest probability of error was obtained in the case of class III. This assessment allows obtaining answers about the correct classification of unknown cases when the discriminant variables detected on the basis of known cases were used for the classification.

For the purpose of comparison of results of PCA and LDA methods, the number and percentage of misclassified cases were calculated (Tab. 4) on the basis of Figure 3 (for the results of PCA method). This method resulted in the largest number of erroneous qualify especially in the II and III classes.

Table 4. Number of observations and percentage (in brackets) classified into Kraft classes

\begin{tabular}{|c|c|c|c|c|c|c|c|c|c|c|c|c|c|c|c|}
\hline & \multicolumn{5}{|c|}{$\begin{array}{l}\text { LDA } \\
\text { the square classification function }\end{array}$} & \multicolumn{5}{|c|}{$\begin{array}{c}\text { LDA } \\
\text { the classification functions } \\
\text { designated by cross-validation } \\
\text { method }\end{array}$} & \multicolumn{5}{|c|}{$\begin{array}{c}\text { PCA } \\
\text { visual assessment }\end{array}$} \\
\hline & \multicolumn{5}{|c|}{ classified as } & \multicolumn{5}{|c|}{ classified as } & \multicolumn{5}{|c|}{ classified as } \\
\hline Kraft class & I & II & III & IV & jointly & I & II & III & IV & jointly & I & II & III & IV & jointly \\
\hline I & $\begin{array}{c}10 \\
(91)\end{array}$ & $\begin{array}{c}1 \\
(9)\end{array}$ & $\begin{array}{c}0 \\
(0)\end{array}$ & $\begin{array}{c}0 \\
(0)\end{array}$ & $\begin{array}{c}11 \\
(100)\end{array}$ & $\begin{array}{c}9 \\
(82)\end{array}$ & $\begin{array}{c}2 \\
(18)\end{array}$ & $\begin{array}{c}0 \\
(0)\end{array}$ & $\begin{array}{c}0 \\
(0)\end{array}$ & $\begin{array}{c}11 \\
(100)\end{array}$ & $\begin{array}{c}9 \\
(82)\end{array}$ & $\begin{array}{c}2 \\
(18)\end{array}$ & $\begin{array}{c}0 \\
(0)\end{array}$ & $\begin{array}{c}0 \\
(0)\end{array}$ & $\begin{array}{c}11 \\
(100)\end{array}$ \\
\hline II & $\begin{array}{c}1 \\
(1)\end{array}$ & $\begin{array}{c}98 \\
(98)\end{array}$ & $\begin{array}{c}1 \\
(1)\end{array}$ & $\begin{array}{c}0 \\
(0)\end{array}$ & $\begin{array}{c}100 \\
(100)\end{array}$ & $\begin{array}{l}1 \\
(1)\end{array}$ & $\begin{array}{c}98 \\
(98)\end{array}$ & $\begin{array}{c}1 \\
(1)\end{array}$ & $\begin{array}{l}0 \\
(0)\end{array}$ & $\begin{array}{c}100 \\
(100)\end{array}$ & $\begin{array}{c}5 \\
(5)\end{array}$ & $\begin{array}{c}93 \\
(93)\end{array}$ & $\begin{array}{c}2 \\
(2)\end{array}$ & $\begin{array}{c}0 \\
(0)\end{array}$ & $\begin{array}{c}100 \\
(100)\end{array}$ \\
\hline III & $\begin{array}{c}0 \\
(0)\end{array}$ & $\begin{array}{c}4 \\
(15)\end{array}$ & $\begin{array}{c}21 \\
(81)\end{array}$ & $\begin{array}{c}1 \\
(4)\end{array}$ & $\begin{array}{c}26 \\
(100)\end{array}$ & $\begin{array}{c}0 \\
(0)\end{array}$ & $\begin{array}{c}6 \\
(23)\end{array}$ & $\begin{array}{c}18 \\
(69)\end{array}$ & $\begin{array}{c}2 \\
(8)\end{array}$ & $\begin{array}{c}26 \\
(100)\end{array}$ & $\begin{array}{c}0 \\
(0)\end{array}$ & $\begin{array}{c}4 \\
(15)\end{array}$ & $\begin{array}{c}20 \\
(77)\end{array}$ & $\begin{array}{c}2 \\
(8)\end{array}$ & $\begin{array}{c}26 \\
(100)\end{array}$ \\
\hline IV & $\begin{array}{c}0 \\
(0)\end{array}$ & $\begin{array}{c}0 \\
(0)\end{array}$ & $\begin{array}{c}1 \\
(7)\end{array}$ & $\begin{array}{c}14 \\
(93)\end{array}$ & $\begin{array}{c}15 \\
(100)\end{array}$ & $\begin{array}{c}0 \\
(0)\end{array}$ & $\begin{array}{c}0 \\
(0)\end{array}$ & $\begin{array}{c}2 \\
(13)\end{array}$ & $\begin{array}{c}13 \\
(87)\end{array}$ & $\begin{array}{c}15 \\
(100)\end{array}$ & $\begin{array}{c}0 \\
(0)\end{array}$ & $\begin{array}{c}1 \\
(7)\end{array}$ & $\begin{array}{l}1 \\
(7)\end{array}$ & $\begin{array}{c}13 \\
(86)\end{array}$ & $\begin{array}{c}15 \\
(100)\end{array}$ \\
\hline Jointly & $\begin{array}{l}11 \\
(7)\end{array}$ & $\begin{array}{l}103 \\
(68)\end{array}$ & $\begin{array}{c}23 \\
(15)\end{array}$ & $\begin{array}{c}15 \\
(10)\end{array}$ & $\begin{array}{c}152 \\
(100)\end{array}$ & $\begin{array}{l}10 \\
(6)\end{array}$ & $\begin{array}{l}106 \\
(70)\end{array}$ & $\begin{array}{c}21 \\
(14)\end{array}$ & $\begin{array}{c}15 \\
(10)\end{array}$ & $\begin{array}{c}152 \\
(100)\end{array}$ & $\begin{array}{l}14 \\
(9)\end{array}$ & $\begin{array}{l}100 \\
(66)\end{array}$ & $\begin{array}{c}23 \\
(15)\end{array}$ & $\begin{array}{c}15 \\
(10)\end{array}$ & $\begin{array}{c}152 \\
(100)\end{array}$ \\
\hline A priori & 0.072 & 0.658 & 0.171 & 0.099 & 1.000 & 0.072 & 0.658 & 0.171 & 0.099 & 1.000 & 0.072 & 0.658 & 0.171 & 0.099 & 1.000 \\
\hline \multicolumn{16}{|c|}{ the likelihood of erroneous qualifying } \\
\hline A posteriori & 0.091 & 0.020 & 0.192 & 0.067 & 0.059 & 0.182 & 0.020 & 0.308 & 0.133 & 0.092 & 0.182 & 0.070 & 0.231 & 0.133 & 0.112 \\
\hline
\end{tabular}




\section{Discussion}

It is worth noting that multi-dimensional analyses have been used for the classification of trees in a small degree so far. This issue has been raised by GralaMichalak and Kaźmierczak (2011) as well as Zawieja and Kaźmierczak (2015). However, in these studies, the LDA was used for Scots pine stands and traits associated with the crown were not used.

In the paper, strong correlation was found between tree diameter and height, tree diameter and crown projection area and tree height and crown length. According to the PCA results, crown projection area and diameter have the strongest influence on the biosocial differentiation of trees. In discriminant analysis - applied where the classification of trees is known - the largest contribution in the first discriminant variable had traits $h$ and $d_{1.3}$ and that in the second variable had traits $p k$ and $d_{1.3}$. The influence of crown length appeared to be not clear.

There is objection to the Kraft classification, in the scientific community, because of its subjectivity. However, according to research, Kraft classes indeed grouped trees of similar growth energy and production potential. Owing to this, the secondary division is important in economic point of view. Results of Kaźmierczak researches (2013b) shown that biosocial position of tree significantly influenced increments of Scots pine trees. Retrospective analysis of growth and increments in 50-year-old pine stand (Lemke 1972) shown all curves of current volume increment located one over another in sequence, corresponding to the biosocial classes of trees. Similar results were obtained by Šmelko (1982) for beech and spruce. Borowski (1974) stated that growth curves drafted for mean values within Kraft classes show the same properties from the very young period of tree life, whilst those drafted for individual trees often intersect one another in young age. It means that trees were changing their position during the period. Such a change in position was also reported by Żółciak (1963) for increments of Scots pine stand. Krzysik (after Jaworski 2004) reported that a majority of white fir trees had changed their position in their life. According to the results presented by Beker (2008), biosocial differentiation of trees starts at a very early stage of stand development. The changes occur at approximately $40 \%$ of trees.
As it was mentioned in the introduction, crown of tree has a big impact on growth as both regards determining the assimilation process and its effectiveness in growth of a tree. Moreover, size of a crown is decisive in occupying the growth space of a tree. The latter aspect was a subject of research of Kaźmierczak (2009, 2012b) on Scots pine trees, Kaźmierczak and Stosik (2008) on oaks (Quercus L.) and Kaźmierczak et al. (2010) on larches.

Evaluation of crown development can form a basis for the assessment of damage of single trees, stands and entire forest complexes (Gruber 1987, 1992; Dmyterko 1994; Bruchwal, and Dmyterko 2007; Dmyterk, and Bruchwald 2007a, b; Jaszczak and Miotke 2009; Lesiński et al. 1992).

Crown size also influences stem wood structure, deciding on its quality and - finally - affecting economical result of silviculture. Jelonek et al. (2013) found that some mechanical characteristics of wood material, notably compressive strength and static bending resistance, are positively correlated with the height of tree and crown width, whilst negatively correlated with DBH and tree crown length. Wasik (2010) concluded that Douglass firs of long and wide crowns shows significantly wider annual diameter increments to individuals of short and narrow crowns. According to Fabisiak (2005), the wider the annual rings in coniferous wood are, the lower is the share of late wood and, consequently, the worse are the mechanical properties of wood.

As indicated in the results of research, the influence of crown size on the properties of juvenile wood, generally weaker to mature wood, is especially notable (Amarasekara and Denne 2002; Jakubowski 2004; Mansfield et al. 2007). As shown in the research of Tomczak (2014), properties of juvenile wood produced in different periods of tree life correlate with biometric characteristics of trees, DBH and crown length in particular: juvenile wood of lower quality should be expected on trees of bigger dimensions. Pazdrowski (1994) stated that dimensional characteristic of tree crowns can be of use as predictors in approximation of wood without defects share in bottom log of stem.

Investigation on wood of teak trees from Nigeria proved strong correlation of relative crown length with the length of useful wood log, stem length, crown length and volume (Popoola and Adesoye 2012). Interesting findings were published by Chinese researchers 
(Jiang and Liu 2011) who applied relative crown length in their model of longitudinal cross-section of stems of larch with the determination coefficient $98 \%$. This finally corroborates results of earlier investigations on crown size onto longitudinal cross-sections of trees (Muhairwe 1994; Sharma and Zhang 2004; Jiang et al. 2007).

Svensson's (1998) research on very broad material comprising Scots pine and spruce sample trees indicated that relative crown length should be considered in volume increment prediction. Skrzyszewski (1995) found out significant correlation between crown length and current 10-year basal area increment in 11 from 15 measured spruce stands and between relative crown length and the latter - in 9 from 15 stands. The correlation was even more apparent in larch stands - basal area increment was significantly correlated with crown width and length, in six from the investigated stands, whilst with relative crown length, in four from stands under researches.

Borowski (1968) worked out that it is not only crown size and space occupied by a tree that influences increment but the most important factor is biosocial position. It was apparent in 44-year-old stand that volume increment per unit of crown projection area was lower at trees of large crowns. Amongst trees of comparable crown size, the bigger the volume increment per unit of crown projection area, the higher is the position of a tree. Therefore, trees of high biosocial position compact crowns seem to be the most effective in wood production. Similar regularity was pointed out by Zajączkowski (1973). Research by Dudek (1969) highlighted the influence of age on DBH increment and volume growth intensity (volume increment per unit of basal area) - younger trees of comparable crown projection areas appear to carry out bigger increment than older ones.

Relative crown length may be applied as predictor in tree and stand growth equations, especially for mixed, multi-storey stands, notably by Bella (1971), Sprinz and Burkhart (1987). Assmann (1970) mentioned it amongst measures of growth energy; so as Hasenauer and Monserud (1996). In general, relative crown length is reported to diminish with increase in tree, so as the intensity of competition.

In Poland, crown length and relative crown length were the subject of studies of many researchers includ- ing Jaworski et al. (1988, 1995), Turski et al. (2012), Skrzyszewski (1993, 1995) and Żybura (1988).

Żybura (1988) revealed dependence of crown length on age and site quality and biosocial position. The correlation with age and biosocial position appeared to be strong, whilst the one with site index is not significant. At young pine trees, relative crown length assumed mean value of $45 \%$ of total height; at older ones, it is $33 \%$.

In the research of Jaworski (1979), pre-dominant and dominant firs in single-storey, mixed aged stand (more than 100 years on an average) shown relative crown length ranging from $29 \%$ to $60 \%$. In another study (Jaworski et al. 1995), the same author reported average relative crown length of $42 \%$ for younger and $31 \%$ for older trees from dominating stand.

Turski et al. (2012) reported increase in average relative crown length with age: in 92-year-old stand, it was 1.2 times bigger than that in 77-year-old stand and 1.3 times bigger than in that 47 -year old stands. In every case, relative crown length decreased with the fall of biosocial position.

Kaźmierczak (2012a) highlighted the correlation of pine crown length with current 10 -year volume increment, thickwood volume, DBH and tree height. Also the relative crown length correlated with current 10 -year volume increment, thickwood volume and DBH. The biggest relative crown lengths characterised dominant trees from the youngest stand. Both the crown length and relative crown length were correlated with crown projection area, width of crown, crown spread and growth space of single tree.

\section{Conclusions}

- Analysis of dimensional traits of oaks from 135-yearold stand allows quite certain classification of trees into three groups: pre-dominant (I), dominant and co-dominant (II and III) and dominated ones (IV). This seems to be quite promising, providing a tool for the approximation of the biosocial position of tree with no need for the assessment in forest.

- Applied analyses do not allow distinguishing trees belonging to II and III Kraft class.

- Unless the eye-estimation-based classification is completed, PCA method provided simple, provi- 
sional solution for grouping trees from 135-year-old stand into three above-mentioned groups.

- The discriminant variable, determined based on the known sample tress' given age, allows to properly allocate trees, which has not been determined Kraft class, into three classes (it is based on the results given in Tab. 4).

- Discriminant analysis gives more precise results compared with PCA because of the possibility to determine the discriminant function.

- Visually, both methods give the same effect (Fig. 3 and 4).

- In the analysed stand, the most important traits for evaluation biosocial position were $\mathrm{DBH}$, crown projection area and height.

\section{References}

Amarasekara H., Denne M.P. 2002. Effects of crown size on wood characteristics of Corsican pine in relation to definitions of juvenile wood, crown for med and core wood. Forestry, 75 (1), 51-61.

Assmann E. 1970. The principles of forest yeald study. Pergamon, Oxford, NewYork.

Beker C. 2008. Zmiana struktury biosocjalnej w niepielęgnowanych drzewostanach sosnowych. [Changes in the biosocial structure of unthinned Scots pine stands]. Sylwan, 5, 44-51 [in Polish].

Bella I.C. 1971. A new competition model for individual trees. Forest Science, 17, 364-372.

Borowski M. 1968. Udział klas biosocjalnych w przyroście drzewostanu sosnowego. [Participation, of biosocial classes in increment of pine stand]. Folia Forestalia Polonica, Seria A - Leśnictwo, 19, 117-134 [in Polish].

Borowski M. 1974. Przyrost drzew i drzewostanów. PWRiL, Warszawa.

Bruchwald A., Dmyterko E. 2007. Reakcja przyrostowa świerka w powiązaniu ze stopniem uszkodzenia korony. [Increment reaction of Norway spruce in connection with the crown damage level]. Sylwan, 151 (11), 22-34 [in Polish].

Dmyterko E. 1994. Metody określania stopnia uszkodzenia drzewostanów sosnowych przez emisje przemysłowe. [Methods for determining the degree of damage to pine stands by industrial emissions]. Prace IBL, 782, 128-155 [in Polish].

Dmyterko E., Bruchwald A. 2007a. Kryteria określania uszkodzenia świerka. [Criteria for assessment of the damage to Norway spruce]. Sylwan, 151 (6), 12-23 [in Polish].

Dmyterko E., Bruchwald A. 2007b. Drzewostanowa metoda określania uszkodzenia świerka. [Method of assessment the damage to Norway spruce stand]. Sylwan, 151 (6), 24-33 [in Polish].

Dudek A. 1969. Zależność intensywności przyrostu miąższości i przyrostu pierśnicy od wielkości korony. [The relationship of intensity of tree volume increment and the increment of DBH of crown size]. Folia Forestalia Polonica, Seria A-Leśnictwo, 15, 149-169 [in Polish].

Fabisiak E. 2005. Zmienność podstawowych elementów anatomicznych i gęstości drewna wybranych gatunków drzew. [The variability of the basic elements of anatomy and wood density of selected species of trees]. Roczniki Akademii Rolniczej w Poznaniu, Rozprawy Naukowe, 369, 1-176 [in Polish].

Grala-Michalak J., Kaźmierczak K. 2011. Discriminant analysis for Kraft's classes of trees. Biometrical Letters, 48 (1), 67-81.

Gruber F. 1987. Das Verzweigungssystem und der Nadelfall der Fichte [Picea abies (L.) Karst.] als Grundlage zur Beurteiung von Waldschäden. Berichte des Forschungszentrums Waldökosysteme/ Waldsterben, Reihe A, 26.

Gruber F. 1992. Dynamik und Regeneration der Gehölze. Baumarchitektur auf ökologisch-dynamischer Grundlage und zur Bioindikation am Beispiele der Europäischen Fichte [Picea abies (L.) Karst.], Weiâtanne (Abies alba Mill.), Douglasie (Pseudotsuga menziensii Franco) und Europäischen Lärche (Larix decidua Mill.). Berichte des Forschungszentrums Waldökosysteme, Reihe A, 86/I, 1-420.

Hasenauer H., Monserud R.A. 1996. A crown ratio model for Austrian forests. Forest Ecology and Management, 84, 49-60.

Jakubowski M. 2004. Proportion of juvenile and mature wood in stems of Norway spruce (Picea abies (L.) Karst.) versus the volume of tree crowns. Annals of Warsaw Agriculture University - SGGW. Forestry and Wood Technology, 55, 254-258. 
Jaszczak R., Miotke M. 2009. Defoliacja górnej części i całej korony drzew sosny zwyczajnej (Pinus sylvestris L.). [Defoliation of the top part and entire crown of Scots pine (Pinus sylvestris L.)]. Sylwan, 153 (9), 607-616 [in Polish].

Jaworski A. 1979. Charakterystyka hodowlana wybranych drzewostanów z udziałem jodły (Abies alba Mill.) w Karpatach i Sudetach. [Characteristics breeding of selected stands of fir (Abies alba Mill.) in the Carpathians and the Sudeten Mountains]. Acta Agraria et Silvestria, Series Silvestris, 18 [in Polish].

Jaworski A. 2004. Podstawy przyrostowe i ekologiczne odnawiania oraz pielęgnacji drzewostanów. [Fundamentals of incremental and ecological regeneration and stands tending]. PWRiL, Warszawa [in Polish].

Jaworski A., Kaczmarski J., Pach M., Skrzyszewski J., Szar J. 1995. Ocena żywotności drzewostanów sosnowych w oparciu o cechy biomorfologiczne koron i przyrost promienia pierśnicy. [Assessment of viability of pine stands based on biomorphological traits of crowns and increment in breast height radius]. Acta Agraria et Silvestria, Series Silvestris, 33 [in Polish].

Jaworski A., Podlaski R., Sajkiewicz P. 1988. Kształtowanie się zależności między żywotnością i cechami biomorfologicznymi korony a szerokością słojów rocznych u jodeł. [The dependence between viability and biomorphological traits of the crown, and width of annual rings in firs]. Acta Agraria et Silvestria, Series Silvestris, 27 [in Polish].

Jelonek T., Walkowiak R., Jakubowski M., Tomczak A. 2013. Wskaźniki stabilności drzew w drzewostanach sosnowych uszkodzonych przez wiatr. [Indices of tree stability in Scots pine stands damaged by wind]. Sylwan, 157 (5), 323-329 [in Polish].

Jiang L., Brooks J.R., Hobbs G.R. 2007. Using crown ratio in yellow-poplar compatible taper and volume equations. Northern Journal of Applied Forestry, 24, 271-275.

Jiang L., Liu R. 2011. Segmented taper equations with crown ratio and stand density for Dahurian Larch (Larix gmelinii) in Northeastern China. Journal of Forestry Research, 22 (3), 347-352.

Kaźmierczak K. 2009. Wybrane miary przestrzeni wzrostu pojedynczego drzewa w bliskorębnym drzewostanie sosnowym. [Selected measures of the growth space of a single tree in maturing pine stand]. Sylwan, 5, 298-303 [in Polish].

Kaźmierczak K. 2010. Kształtowanie się wybranych cech przestrzeni wzrostu pojedynczego drzewa w 50-letnim drzewostanie sosnowym. [Selected measures of the growth space of a single tree in 50-years-old Scots pine stand]. Sylwan, 154 (4), 267-274 [in Polish].

Kaźmierczak K. 2012a. Długość koron sosen w drzewostanach trzech klas wieku. [Pine tree crown length in stands of three age classes]. Forestry Letters, 103, 25-32 [in Polish].

Kaźmierczak K. 2012b. Przestrzeń wzrostu sosny w 35-letnim drzewostanie na przykładzie wybranych miar przestrzeni wzrostu pojedynczego drzewa. [Selected measures of the growth space of a single tree in a 35-years-old pine stand]. Sylwan, 156 (4), 280-286 [in Polish].

Kaźmierczak K. 2013a. Biosocjalne zróżnicowanie miąższości grubizny sosen drzewostanów trzech klas wieku oraz jej związki z przestrzenią wzrostu drzewa. [Biosocial diversity of volume of merchantable timber in Scots pine stands in three age classes and its relationships with a tree's growth space]. Sylwan, 157 (2), 122-129 [in Polish].

Kaźmierczak K. 2013b. Zróżnicowanie bieżącego przyrostu sosen w trzech klasach wieku. [The current growth increment of pine tree stands comprising three different age classes]. Leśne Prace Badawcze, 74 (2), 93-100 [in Polish].

Kaźmierczak K., Pazdrowski W., Nawrot M., Szymański M. 2010. Przestrzeń pojedynczego drzewa w drzewostanie panującym w zależności od wieku oraz typu siedliskowego lasu w na przykładzie modrzewia (Larix decidua Mill.). [Single tree space in a dominant stand in relation to age and forest habitat type on the example of larch (Larix decidua Mill.)]. Sylwan, 154 (11), 764-772 [in Polish].

Kaźmierczak K., Stosik M. 2008. Analiza wybranych cech przestrzeni wzrostu pojedynczego drzewa na przykładzie 135-letniego drzewostanu dębowego. [Analysis of selected traits of the growth space of a single tree on the example of a 135 years old oak stand]. Sylwan, 152 (2), 3-9 [in Polish].

Kaźmierczak K., Zawieja B. 2015. The method of standing trees allocation to different biosocial classes. Colloquium Biometricum, 45, 75-92. 
Kraft G. 1884. Beiträge zur Lehre von den Durchforstungen, Schlagstellungen und Lichtungshieben. Klindworth, Hannover.

Krzyśko M. 2000a. Wielowymiarowa analiza statystyczna. Wydawnictwo UAM, Poznań, 211-216.

Krzyśko M. 2000b. Wielowymiarowa analiza statystyczna. Wydawnictwo UAM, Poznań, 263-273.

Lemke J. 1966. Korona jako kryterium oceny dynamiki wzrostowej drzew w drzewostanie sosnowym. [Crown as a criterion for assesment of growth dynamics in pine stands]. Folia Forestalia Polonica, Seria A - Leśnictwo, 12, 185-236 [in Polish].

Lemke J. 1968. Związek pomiędzy wielkością korony a przyrostem drzew w drzewostanach sosnowych. [Relationship between the crown size and tree increment in Scots pine stands]. Prace Komisji Nauk Rolniczych i Komisji Nauk Leśnych PTPN, 25, 43-90 [in Polish].

Lemke J. 1972. Retrospektywna analiza wzrostu i przyrostu drzew w 50-letnim drzewostanie sosnowym. [Retrospective analysis of growth and increment in trees of a 50 years old pine stand]. Folia Forestalia Polonica, Seria A - Leśnictwo, 19, 5-23 [in Polish].

Lesiński J.A., Dmyterko E., Grzyb M. 1992. Skandynawska metoda oceny uszkodzenia sosny i świerka. [Scandinavian method of assessing damage to pine and spruce]. Sylwan, 136 (6), 19-31 [in Polish].

Mansfield S.D., Parish R., Goudie J.W., Kang K.Y., Ott P. 2007. The effects of crown ratio on the transition from juvenile to mature wood production in lodgepole pine in western Canada. Canadian Journal of Forest Research, 37 (8), 1450-1459.

Muhairwe C.K. 1994. Tree form and taper variation over time for interior lodgepole pine. Canadian Journal of Forest Research, 24, 1904-1913.

Pazdrowski W. 1994. Współzależność między niektórymi cechami ilościowymi koron drzew a makrostrukturą drewna sosen (Pinus sylvestris L.) wyrosłych w warunkach BMśw. [Interdependence between some quantitative traits tree crowns and wood macrostructure pines (Pinus sylvestris L.) grown on fresh mixed coniferous.]. Sylwan, 138 (11), 79-88 [in Polish].

Popoola F.S., Adesoye P.O. 2012. Crown ratio models for Tectona grandis (Linn. f.) stands in Osho Forest Reserve, Oyo State, Nigeria. Journal of Forest Science, 28 (2), 63-67.
Sharma M., Zhang S.Y. 2004. Variable-exponent taper equations for jack pine, black spruce, and balsam fir in eastern Canada. Forest Ecology and Management, 198, 39-53.

Skrzyszewski J. 1993. Kształtowanie się zależności między żywotnością oraz cechami biomorfologicznymi korony a masą korzeni i szerokością słoi rocznych u świerka i modrzewia. [The development of the relationship between vitality and morphological crown and root mass and width of annual grain of spruce and larch]. Katedra Szczegółowej Hodowli Lasu AR Kraków [in Polish].

Skrzyszewski J. 1995. Charakterystyka przyrostowa oraz kształtowanie się zależności pomiędzy wybranymi cechami drzew a przyrostem promienia na pierśnicy świerka i modrzewia. [Increment characteristic and fluctuations in the dependence between selected traits of trees and radial increment at breast height in spruce and larche]. Acta Agraria et Silvestria, Series Silvestris, 33, 141-158 [in Polish].

Šmelko S. 1982. Biometrickie zakonitosti rastu a prirastku lesnych stromov a porastov. Veda, Bratislava.

Sprinz P.T., Burkhart H.E. 1987. Relationships between tree crown, stem and stand characteristics in unthinned loblolly pine plantations. Canadian Journal of Forest Research, 17, 534-538.

Svensson S.A. 1998. Estimation of annual stem volume increment. SUAS, Department of Forest Survey, Report 46, Umea.

Tomczak A. 2014. Związki między wybranymi cechami drzewa a niektórymi właściwościami drewna młodocianego sosny zwyczajnej (Pinus sylvestris L.). [Relationships between selected tree characteristics and the properties of juvenile wood in Scots pine (Pinus sylvestris L.)]. Leśne Prace Badawcze, 75 (3), 237-244. DOI, 10.2478/frp-2014-0023 [in Polish].

Turski M., Jaszczak R., Deus R. 2012. Wybrane charakterystyki koron drzew i ich związek z pierśnicą oraz wysokością w drzewostanach sosnowych różnych klas wieku. [Selected traits of tree crowns and their relationship with the dbh and height in pine tree-stands of different age classes]. Sylwan, 156 (5), 369-378 [in Polish].

Wąsik R. 2010. Związki między wybranymi parametrami korony a cechami makrostruktury i gęstością drewna daglezji zielonej (Pseudotsuga menziesii var. viridis Franco). [Relationships between se- 
lected crown parameters and the macrostructure properties and density of Douglas fir (Pseudotsuga menziesii var. viridis Franco) wood]. Sylwan, 154 (11), 783-790 [in Polish].

Zajączkowski J. 1973. Przyrost miąższości w klasach biosocjalnych starszych drzewostanów sosnowych. [The increment of tree volume in biosocial classes of older pine stands]. Sylwan, 1, 1-9 [in Polish].

Zawieja B., Kaźmierczak K. 2015. The method of standing trees allocation to different biosocial classes. Colloquium Biometricum, 45, 78-92.

Żółciak E. 1963. Analiza kształtowania się przyrostów drzew w różnych okresach życia drzewostanów sosnowych w borze świeżym na przykładzie Nad- leśnictwa Doświadczalnego WSR Zielonka. [An analysis of the shaping of the growth rings at trees in various periods of life in a pine stand as shown on the example of the fresh forest at Zielonka Experimental Forest Station]. Roczniki WSR w Poznaniu, 14, 249-293 [in Polish].

Żybura H. 1988. Relation of the crown length of pine trees to the age and site quality of stand and to the biosocial structure of trees. Annals of Warsaw Agricultural University. Forestry and Wood Techno$\log y, 36$.

http//stat.gov.pl/obszary-tematyczne/rolnictwo-lesnictwo/lesnictwo/lesnictwo-2014,1,10.html 